First publ. in: International Interactions 36 (2010), 2, pp. 107-114

\title{
The Capitalist Peace: The Origins and Prospects of a Liberal Idea
}

\author{
GERALD SCHNEIDER \\ University of Konstanz and Centre for the Study of Civil War, PRIO \\ NILS PETTER GLEDITSCH \\ PRIO and Norwegian University of Science and Technology, Trondheim
}

Heralding the "end of history," Fukuyama (1992) infamously forecast the total triumph of the twin sisters of liberalism - capitalism and democracy. Twenty years later, over one-third of the world's population live in countries characterized as "not free" (Freedom House 2009) and the economic crisis that a frenzied financial sector has brought over the world has considerably tarnished the public perception of the capitalist organization of markets. History is thus far from over, and the "victory" of the liberal coalition led by the United States seems to have been squandered.

Such developments, however, do not relieve social scientists from the necessity to uncover whether the main attributes of a liberal state - free elections and market economies - have the side effects often attributed to them. One of these hotly debated outcomes is the peace-building effect of democracy and capitalism that Schumpeter (1919) sketched after World War I and that Weede (2003) finally labelled Capitalist Peace. ${ }^{1}$ Proponents of this variant of the liberal thesis argue that capitalism renders states more statusquo-oriented and less concerned with traditional security issues. They expect that various facets of capitalism, ranging from increased development to

\footnotetext{
${ }^{1}$ Outside of the social sciences, the idea has a much older history. In the journals covered by Jstor, the first coinage of the "capitalist peace" is made in a review of a book that questions the role of the U.S. labor movement during World War I (Simpson 1941). A Google books-search dug up an equally critical World War I pamphlet by a presidential candidate of the Socialist Party of America (Benson 1915).

Most of the articles assembled in this special issue were presented at three panels sponsored by the International Studies Association at the Fifth General Conference of the European Consortium for Political Research, Potsdam, Germany, September 10-12, 2009. Our work has been supported by the German Peace Research Foundation (Schneider) and the Research Council of Norway (Gleditsch).

Address correspondence to Gerald Schneider, Department of Politics and Management, University of Konstanz, Box D 86, Konstanz, D-78457, Germany. E-mail: Gerald.schneider@ uni-konstanz.de or Nils Petter Gleditsch, Centre for the Study of Civil War, PRIO, P.O. Box 9229 Grønland, 0134 Oslo, Norway. E-mail: nilspg@prio.no
} 
free trade and foreign investment, are positively related to peace. In view of the continuing controversies over the advantages and disadvantages of capitalism it is not surprising that this view is contested. Drawing on the theory of imperialism, Hilferding (1947 [1910]), Lenin (1921 [1917]), and other Marxian writers as well as more modern supporters of dependency theory and critical theory see in capitalism one of the key harbingers of crisis and war (see, e.g., Packer 2003).

Despite these controversies, the peace-through-capitalism thesis has only recently received systematic scrutiny by the conflict research community, in the wake of a period where the liberal research agenda was dominated first by the democratic peace (Doyle 1986), then by the Kantian peace (Russett and Oneal 2001). However, Rummel (1979, 1983) wrote of the pacific effects of libertarianism, including economic freedom, long before he switched to the more mainstream term of democracy. He advocated a monadic thesis ("Freedom inhibits violence," Rummel, 1979:292) as well as a dyadic thesis ('Libertarian systems mutually preclude violence,' p. 277). He further formulated a 'Positive Peace Principle' ('Minimize the power of government,' Rummel 1981:266) in direct opposition to the concept of positive peace developed by Galtung (1969), which he saw as a 'socialist theory of peace' (p. 83). Early peace researchers (Russett 1967; Wallensteen 1973) had studied some key features of capitalism, notably trade, but capitalism itself generally had a negative image in the founding years of peace research (Gleditsch 2008:707). In his most frequently cited article, Galtung (1971) saw asymmetric trade as an important form of imperialism ${ }^{2}$, views echoed to some extent in the critique of commercial liberalism by Barbieri (2002). Interestingly, the twentieth century foundations of this argument by Angell (1910) precedes the Schumpeterian vision that capitalist entrepreneurship and democracy go hand in hand as a source of peace. The analytically narrower peace-through-trade literature, which was reinvigorated by Rosecrance (1986) and which Nye (1988) dubbed "commercial liberalism," focuses exclusively on how the international activities of economic actors influence foreign policy choices and, by extension, the bilateral and multilateral relations of states. How other aspects of capitalism such as the protection of property rights or the lack of interventionist economic policies might affect foreign policy decisions remained largely unexplored. Toward the end of the Cold War, Mueller (1989) observed that industrialized countries rarely if ever fought each other, and ten years later he argued that democracy was overrated but that capitalism did not get enough credit (Mueller 1999).

\footnotetext{
${ }^{2}$ Although Galtung's reconceptualization of the Marxist theory of imperialism also entailed a critique of capitalism, he did not limit his negative appraisal of imperialism to the capitalist form.
} 
That the capitalist peace argument lay dormant so long in the quantitative literature is astonishing in light of Bremer's (1992) landmark study, which introduced dyads as the standard unit of analysis for research on interstate war. He established that joint development strongly decreases the likelihood of conflict. A theoretical basis for a peace based on free trade was sketched by Weede (1995), who undertook one of the first systematic attempts to weave the organization of markets into a more general liberal argument. Nevertheless, it took several years until such claims were further developed and systematically contrasted with the empirical evidence. This first wave of capitalist peace studies highlighted how capitalist markets create peaceful preferences and how the level of development conditions the liberal peace (Hegre 2000; Mousseau 2000; Mousseau, Hegre, and Oneal 2003). Mousseau (2000, 2009), as well as Gartzke were the first to challenge the Kantian peace in an econometric study based on this emerging literature. Gartzke argued that the democratic peace was just an epiphenomenon of capital openness and free trade. McDonald (2009), using similar methods, found the capitalist peace to condition but not to invalidate the democratic peace, while Mousseau (2009) provides an unconditional test of his earlier argument (2000) that capitalism can cause two main components of the Kantian Peace, democracy and trade, as well as peace.

This special issue explores whether and how such findings alter the liberal research agenda. To this end, we have organized a debate that unites leading capitalist peace scholars as well as some prominent sceptics. In this introduction, we discuss the main research traditions and assess their relative merits before moving on to a presentation of the research articles and the challenges that future research has to confront.

\section{THE CURRENT DEBATE AND THE MAIN CHALLENGES}

We can generally distinguish between four main arguments in favor of the capitalist peace. The first one is based on a hedonistic understanding of human nature and argues that capitalism alters human behavior and transforms belligerent individuals residing in interventionist states into peace-loving consumers, traders, and business people. The second set of arguments does not share the naïve optimism of the hedonistic school of thought with regard to an unconditional effect of capitalism on state behavior. Proponents of the more skeptical position only believe in the peacefulness of unregulated markets in certain configurations. A key modifying force, introduced by Schumpeter (1919), is democracy. In his view, the power of the capitalist peace conviction within a country depends on the distribution of power between protectionists and the adherents of the market economy who both are able to voice their wishes within a democratic setting. Another conditionality argument maintains that the pacifying influence of 
trade grows with the level of development (Hegre 2000; Mousseau 2000; Mousseau et al. 2003). A third line of reasoning refers to the protection of property rights and argues that the contract intensity of capitalist economies renders them more peaceful (Mousseau 2000, 2010). Drawing on the crisis bargaining literature, a final argument maintains that capitalist economies are better able to signal their resolve than closed economies (Gartzke, Li, and Boehmer 2001; Gartzke 2007).

The contributions to this special issue as well as the invited commentaries reflect the whole range of arguments that have been made in favor of the capitalist peace thesis. Extending the argument in Gartzke (2007), Gartzke and Hewitt (2010) rely on the ICB data on crisis behavior, which overlaps only to a limited degree with the data on interstate disputes used in the earlier work. The crisis data allow them to test not only hypotheses about the onset of conflict, but also about the escalation of conflict and the level of severity. The peace-building effects of capitalism, as measured by financial openness, persist.

McDonald (2010) makes use of a different indicator of capitalism and tests the hypothesis that large quantities of public property heighten the risks of being targeted in a military conflict. Using a monadic as well as a dyadic design he concludes that capitalism does indeed promote peace.

Mueller (2010) focuses on three cultural or attitudinal prerequisites of the capitalist peace, that the growth of economic well-being is a dominant goal; that peace is seen as better than war for promoting innovation, progress, and growth; and that wealth is perceived to be best achieved through exchange rather than conquest.

Gartzke and Hewitt conclude that democracy makes no significant independent contribution to peace, McDonald reaches a more limited conclusion: capitalism plays a larger role than democracy in limiting military conflict between states. Russett (2009, 2010), relying to a large extent on Dafoe (2008) for the empirics, argues that democracy still counts and views the contribution of capitalism as supplementary rather than primary. Mueller thinks that a capitalist peace is more likely than a democratic peace, but sees peace and not capitalism as the determining factor in the relationship.

These contributions and the accompanying comments certainly move us beyond the polarized debate that portrays capitalism either as a source of conflict or as a source of peace. However, the capitalist peace-thesis has to address several challenges if it endeavours to become a real alternative to the Kantian peace or just a qualification of the main liberal arguments. With the exception of the informal arguments advanced by Gartzke (2007), Mousseau (2003, 2009), and McDonald (2009), a key problem of the current capitalist peace literature is its lack of precise micro-foundations that link markets and their main attributes to peace. We do not reject the value of nonformal reasoning. However, the development of the civil war literature has shown that the influence of development on the risk of civil war, for a 
long time considered to be a key finding of this literature, is based on shaky analytical foundations. According to Fearon's (2008) criticism of rent-seeking models of internal war, higher development makes the bounty for the contending forces more attractive, but it makes conflict also more costly as wages and other compensations for the soldiers simultaneously rise. A similar indeterminacy is likely to hurt models that try to link development to conflict. As nations get richer, they can afford security more cheaply and better protect themselves. However, they also become more attractive targets. Developed aggressors face a similar dilemma. They can use their wealth for their fighting capabilities, but also risk destroying more resources through an attack than less developed attackers. If development as an indicator is linked to peace in any meaningful way, it needs to be based on a more convincing theoretical footing.

A related theoretical limitation of some key contributions to the current capitalist peace literature is the use of the same game-theoretic arguments that have been used as a foundation for the democratic peace. If both democracies and capitalist societies are better able to signal their resolve in an interstate crisis and if the models rely on the same set of actors, we are unable to differentiate between the microfoundations of these two strands of liberal scholarship. What is particularly lacking is a clear understanding of how "capitalists" as well as "entrepreneurs" and thus the key actors in the Schumpeterian modelling tradition (cf. McCraw 2007) influence public policymaking. The case study evidence assembled by McDonald (2009) is a step in the right direction, but we need more general support for the claim that capitalists lobby for peace in a systematic fashion. Studies on the interactions between international politics and financial markets strongly suggest that investors are rather opportunistic and adapt their behaviour surprisingly quickly to the policy decisions of government leaders (cf. Bechtel and Schneider 2010).

Empirically, the literature on the capitalist peace is often hard to distinguish from other research programs in the field. For instance, commercial liberalism, one of the established cornerstones of the Kantian peace tripod, never focused exclusively on trade, but encompassed all sorts of economic bonds between nations. It as a major sign of conceptual progress that McDonald (2009) clearly differentiates between the capitalist and the commercial variant of the liberal peace. This separation is, however, unlikely to solve all conceptual problems. Capitalist economic policies that lead to the deeper integration of an economy into international markets should be considered to be one of the ultimate driving forces of capitalist peace, but the level of development is in the light of some economic growth theorists (Sachs and Warner 1995) endogenous to these policy choices. Therefore, by extension, the capitalist peace could be considered being an epiphenomenon of commercial liberalism. This leads to the question of what attributes of a capitalist economy should be used in empirical applications. At the moment, 
there are so many indicators that it is hard to see how the "capitalist peace" differs from rival explanations. Some manifestations of the capitalist peace notion that stress a market economy and a strong state border on what could equally well be called a social-democratic peace.

As is often the case with a new research agenda, such theoretical, conceptual, and empirical challenges will be addressed in the next generation of studies on the capitalist peace. With the publication of this special issue, replication data become available for the articles by McDonald and by Gartzke and Hewitt. Skeptics will no doubt examine their data for robustness and debatable interpretations.

In this issue we concentrate on the relationship between capitalism and interstate peace, but similar research is in progress on intrastate peace (de Soysa and Fjelde 2010). We have invited comments from several colleagues who have shaped the earlier discussion on the interface between foreign policy and the liberal vision of the economy. These comments by Michael Mousseau (2010), Richard Rosecrance (2010), Bruce Russett (2010), and Erich Weede (2010) provide sufficient evidence that the controversies over the capitalist peace thesis will considerably shape the liberal research agenda in conflict studies in the years to come.

\section{REFERENCES}

Angell, Norman. (1910) The Great Illusion. A Study of the Relation of Military Power in Nations to Their Economic and Social Advantages. London: Heinemann.

Barbieri, Katherine. (2002) The Liberal Illusion. Does Trade Promote Peace? Ann Arbor, MI: University of Michigan Press.

Bechtel, Michael M., and Gerald Schneider. (2010) Eliciting Substance from "Hot Air": Financial Market Responses to EU Summit Decisions on European Defense. International Organization 64(2):199-223.

Benson, Allan L. (1915) A Way to Prevent War. Girard, KS: Appeal to Reason. Available at http://www.archive.org/stream/awaytopreventwa02bensgoog\#page/n12/ mode/1up

Bremer, Stuart. (1992) Dangerous Dyads: Conditions Affecting the Likelihood of Interstate War, 1816-1965. Journal of Conflict Resolution 36(2):309-341.

Dafoe, Allan. (2008) Democracy Still Matters: The Risks of Sample Censoring, and Cross-Sectional and Temporal Controls. Unpublished manuscript, Department of Political Science, University of California Berkeley.

De Soysa, Indra, and Hanne Fjelde. (2010) Is the Hidden Hand an Iron Fist? Capitalism \& Civil Peace, 1970-2005. Journal of Peace Research 47(4):287-298.

Doyle, Michael W. (1986) Liberalism and World Politics. American Political Science Review 80(4):1151-1169.

Fearon, James D. (2008) Economic Development, Insurgency, and Civil War. In Institutions and Economic Performance, edited by Elhanan Helpman. Cambridge, MA: Harvard University Press, pp. 292-328. 
Freedom House. (2009) Freedom in the World. New York: Freedom House. Available at http://www.freedomhouse.org

Fukuyama, Francis. (1992) The End of History and the Last Man. New York: Free Press.

Galtung, Johan. (1969) Violence, Peace, and Peace Research. Journal of Peace Research 6(3):167-191.

Galtung, Johan. (1971) A Structural Theory of Imperialism. Journal of Peace Research 8(2):81-117.

Gartzke, Erik. (2007) The Capitalist Peace. American Journal of Political Science 51(1):166-191.

Gartzke, Erik, and J. Joseph Hewitt. (2010) International Crises and the Capitalist Peace. International Interactions 36(2):115-145.

Gartzke, Erik, Quan Li, and Charles Boehmer. (2001) Investing in the Peace: Economic Interdependence and International Conflict. International Organization 55(2):391-438.

Gleditsch, Nils Petter. (2008) The Liberal Moment Fifteen Years On. International Studies Quarterly 52(4):691-712.

Hegre, Håvard. (2000) Development and the Liberal Peace: What Does It Take to Be a Trading State? Journal of Peace Research 37(1):5-30.

Hilferding, Rudolf. (1947 [1910]) Das Finanzkapital. Eine Studie über die jüngste Entwicklung des Kapitalismus (Finance Capital. A Study of the Latest Phase of Capitalist Development). Berlin: Dietz. (English version: Routledge, 1981.)

Lenin, Vladimir I. (1921 [1917]) Der Imperialismus als jüngste Etappe des Kapitalismus [Imperialism: The Highest Stage of Capitalism]. Hamburg: Cahnbley. (Originally published as Imperializm kak novejsij etap kapitalizma. Petrograd: Shisn i Snanije.)

McCraw, Thomas K. (2007) Prophet of Innovation. Joseph Schumpeter and Creative Destruction. Cambridge, MA: Harvard University Press.

McDonald, Patrick J. (2009) The Invisible Hand of Peace: Capitalism, the War Machine, and International Relations Theory. New York: Cambridge University Press.

McDonald, Patrick J. (2010) Capitalism, Commitment, and Peace. International Interactions 36(2):146-168.

Mousseau, Michael. (2000) Market Prosperity, Democratic Consolidation, and Democratic Peace. Journal of Conflict Resolution 44(4):472-507.

Mousseau, Michael. (2003) The Nexus of Market Society, Liberal Preferences, and Democratic Peace: Interdisciplinary Theory and Evidence. International Studies Quarterly 47(4):483-510.

Mousseau, Michael. (2009) The Social Market Roots of the Democratic Peace. International Security 33(4):52-86.

Mousseau, Michael. (2010) Coming to Terms with the Capitalist Peace. International Interactions 36(2):185-192.

Mousseau, Michael, Håvard Hegre, and John R. Oneal. (2003) How the Wealth of Nations Conditions the Liberal Peace. European Journal of International Relations 9(2):277-314.

Mueller, John. (1989) Retreat from Doomsday: The Obsolescence of Major War. New York: Basic Books. 
Mueller, John. (1999) Capitalism, Democracy \& Ralph's Pretty Good Grocery. Princeton, NJ: Princeton University Press.

Mueller, John. (2010) Capitalism, Peace, and the Historical Movement of Ideas. International Interactions 36(2):169-184.

Nye, Joseph S., Jr. (1988) Neorealism and Neoliberalism. World Politics 40(2):235-251.

Packer, Dave. (2003) Capitalism Means War. Socialist Outlook (01). Available at http://www.isg-fi.org.uk/spip.php?article10

Rosecrance, Richard. (1986) The Rise of the Trading State: Conquest and Commerce in the Modern World. New York: Basic Books.

Rosecrance, Richard. (2010). Capitalist Influences and Peace. International Interactions 36(2):192-198.

Rummel, Rudolph J. (1979) Understanding Conflict and War, Volume 4: War, Power, Peace. Beverly Hills, CA: Sage.

Rummel, Rudolph J. (1981) Understanding Conflict and War, Volume 5: The Just Peace. Beverly Hills, CA: Sage.

Rummel, Rudolph J. (1983) Libertarianism and International Violence. Journal of Conflict Resolution 27(1):27-71.

Russett, Bruce (1967) International Regions and the International System: A Study in Political Ecology. Chicago, IL: Rand McNally.

Russett, Bruce. (2009) Democracy, War, and Expansion through Historical Lenses. European Journal of International Relations 15(1):9-36.

Russett, Bruce. (2010) Capitalism or Democracy? Not So Fast. International Interactions 36(2):198-205.

Russett, Bruce, and John R. Oneal. (2001) Triangulating Peace: Democracy, Interdependence, and International Organizations. New York: Norton.

Sachs, Jeffrey D., and Warner, Andrew M. (1995) Economic reform and the process of global integration. Brookings Papers on Economic Activity, 1-118.

Schumpeter, Joseph A. (1919) Zur Soziologie der Imperialismen (Sociology of Imperialisms). Archiv für Sozialwissenschaft und Sozialpolitik 46:1-39 and 275-310. English version in Swedberg, Richard, ed. (1991) The Economics and Sociology of Capitalism. Princeton: Princeton University Press, pp. 141-219.

Simpson, Smith. (1941) Review of Labor in War-time by John Steuben, International Publishers. American Political Science Review 35(2):380.

Wallensteen, Peter. (1973) Structure and War: On International Relations 1920-1968. Stockholm: Raben \& Sjögren.

Weede, Erich. (1995) Economic Policy and International Security: Rent-seeking, Free Trade, and Democratic Peace. European Journal of International Relations 1(4):519-537.

Weede, Erich. (2003) Globalization: Creative Destruction and the Prospect of a Capitalist Peace. In Globalization and Armed Conflict, edited by Gerald Schneider, Katherine Barbieri, and Nils Petter Gleditsch. Lanham, MD: Rowman \& Littlefield, pp. 311-323.

Weede, Erich. (2010) The Capitalist Peace and the Rise of China: Establishing Global Harmony by Economic Interdependence. International Interactions 36(2):206-213. 